\title{
Türkiye Modernleşmesi Karşısında Dini Gruplar
}

\author{
Mahmut Hakkı Akın
}

\begin{abstract}
Öz: Modernleşme ile sekülerleşme arasında yakın bir ilişki olduğu genelde vurgulanmıştır. Türkiye modernleşmesi, kendi tarihsel ve sosyolojik gerçekliğinde din, toplum ve siyaset ilişkisinin sekülerleşme dolayısıyla yorumlanabileceği bir süreç olarak kabul edilebilir. Bu süreçte zamanla eskiye ve geleneksele ait olanlar ile yeni ve modern olanlar arasında kültürel ve siyasal bir mesafe oluşmuştur. II. Meşrutiyet sonrasında tartışılmaya başlanan, cumhuriyetin kurulmasının ardından da toplumsal hayata geçirilen pek çok yenilik, yeni iktidarın sekülerleşme siyasetinin bir sonucu olarak yorumlanmıştır. Öyle ki cumhuriyet modernleşmesi, laiklik ilkesi temelinde bir toplumsal bölünmenin yaşanmasına sebep olmuştur. Yıllardır toplumun geleneksel dini yapısının üretenleri olan dini gruplar ve cemaatler, bu bölünmede iktidar tarafından “öteki” olarak tanımlanmışlardır. Dini grupların kamusal alandaki meşruluklarını kaybetmeleri, yok olmaları anlamına gelmemiş, genelde yer altına çekilerek kendi varlıklarını sürdürmelerine sebep olmuştur. Tek parti iktidarı boyunca devletle gerilimli bir ilişki halinde olan dini gruplar, çok partili hayata geçişle birlikte siyaset ile faydacı bir ilişki halinde olmuşlardır. Siyasi partiler de dini gruplar ile benzer bir fayda ilişkisini gözetmişlerdir. Askeri darbeler yoluyla siyasete müdahale edildiği dönemlerde, bürokratik yapıda tek parti dönemindekine benzer refleksler gösterilmişse de demokrasiye dönülmesiyle birlikte siyasiler ve dini gruplar açısından karşılıklı bir fayda diyalektiği üretilmeye devam edilmiştir. 28 Şubat süreci ve AK Parti iktidarı dönemi, Türkiye modernleşmesinde dini grupların konumu açısından farklı dönemler olarak da dikkat çekmiştir.
\end{abstract}

Anahtar Kelimeler: Türkiye modernleşmesi, dini gruplar, dini cemaatler, laiklik.

\begin{abstract}
It is generally emphasized that there is a close relationship between modernization and secularization. Turkey's modernization process can be regarded as a secularization process of religion, society and politics in relation to Turkey's sociological and historical reality. In the process, a cultural and political distance has developed between the old and the traditional and the new and modern. Many innovations that began to be discussed after the II. Constitutional period and passed on to the social life after the establishment of the republic were interpreted as a result of the policy of secularization of the new government. The modernization of the republic has caused a social division on the basis of secularism. Religious groups and communities, which have been the producers of the traditional religious structure of the society for many years, are defined by the ones in power as "the other" in this division. The loss of legitimacy of those religious groups in the public sphere did not mean that they were destroyed, but it often caused them to go underground in order to continue their existence. Religious groups were in a tense relationship with the state during the single-party rule, after transition to multi-party system, they have had a pragmatic relationship with politics. Political parties also observed a similar benefit relationship with religious groups. Although bureaucratic structures showed similar reflexes to that in the single party period during the period when politics was interfered by military coups, mutual benefit dialect continued to be produced in terms of politics and religious groups with the return of democracy. The period of February 28 and AK Party ruling also attracted attention as different periods in terms of the position of religious groups in the modernization of Turkey.
\end{abstract}

Keywords: Modernization in Turkey, religious groups, religious communities, laicism.

(C) İlmi Etüdler Derneği

DOI: 10.12658/human.society.7.13.M0213

İnsan \& Toplum, 7(1), 2017, 1-24.

insanvetoplum.org 


\section{Giriş}

Türkiye'de modernleşme, genelde kendisine özgü bir toplumsal değişme ve sekülerleşme tecrübesi olarak kabul edilmektedir. Bu süreç, Türkiye dışındaki ilgililerin de dikkatlerini çekmektedir. Yurt içinde ve dişında bu konuyu farklı açılardan ele alan literatürün ciddi bir birikime karşılık geldiği söylenebilir. İki yüzyılı aşan bu süreçte pek çok konuda nesiller ve dönemler arasındaki farklılaşmaları, devamlılıkları ve kopuşları izlemek mümkündür. Farklı dönemlerde farklılaşan siyasetler ve hedefler, toplumsal ve kültürel değişim, farklı fikir hareketlerinin katkıları, Türkiye modernleşmesinin kendisine özgü yapısının gelişmesini sağlamıştır.

Türkiye modernleşmesinin -ki sürecin aynı zamanda bir sekülerleşme tecrübesi olduğu da göz önünde bulundurulduğunda- en önemli ve hassas konularının başında din meselesi gelmiştir. Din, bu süreçte önemli değişimlerin yaşandığı bir alan olarak dikkat çekmektedir. Modernleşmenin başladığı kabul dönemde sembolik bir olay olarak Bektaşi tarikatına bağlı Yeniçeri Ocağı'nın kaldırılması, Tanzimat Fermanında vatandaşlık konusunda dine dayanan tabakalı bir yapı yerine eşitlik vurgusunun yapilması, sürecin başından itibaren fikir ve siyaset üretme konusunda dinin önemli bir etken olduğunu göstermektedir. Ayrıca toplum yapısını ve toplumsal ilişkileri belirleyen en temel ve geleneksel kurumun din olması da bir şekilde din konusunun modernleşme sürecinde öne çıkmasını sağlamıştır. Osmanlı modernleşmesinin ilerleyen dönemlerinde geleneksel dinî kuruluşların karşısında batılı tarzda eğitim veren kuruluşların açılmaya başlaması, dönemin "ilerleme" tartışmalarının ana eksenini "İslam terakkiye mâni midir?" sorusunun belirlemesi, Türkiye'de İslamcılığın önemli bir fikir hareketi olarak ortaya çıkması, farklı eğitim kuruluşlarından yetişen nesiller arasındaki genelde din kurumuna ve özelde İslam'a bakış konusundaki ayrışma, İttihat ve Terakki'ye bağlı düşünürlerin milli bir din üretme düşüncesi ve cumhuriyet döneminin radikal laiklik anlayışı, Türkiye modernleşmesinin sosyolojik okumasında din meselesinin merkezi konumunu göstermeleri açısından önemli örneklerdir. Ayrıca cumhuriyetin laiklik anlayışına bağlı olarak din konusu, hemen her dönemde en önemli siyasi meselelerden birisi olmuştur; olmaya da devam etmektedir.

Müslim ya da gayrı Müslim dini grupların ve cemaatlerin, Osmanlı geleneksel toplumunda sosyal ve kültürel bir gerçeklik olarak dinin üretilmesinde önemli rolleri olmuştur. Osmanlı ve Cumhuriyet modernleşmesi sürecinde toplumun büyük bir kısmı geleneksel, özellikle de gündelik hayat ritüelleri ve sembolleri açısından dinî bir yapıya sahiptir. Ancak özellikle on dokuzuncu asrın ikinci yarısından itibaren açılmaya başlanan eğitim kuruluşlarında yetişen yeni nesiller, geleneksel 
yapıdan gelmelerine rağmen aldıkları yatılı ve kapalı eğitimin yanında akranlarıyla dahil oldukları ve karşılıklı olarak ürettikleri sosyalleşme tecrübelerinin etkileriyle içinden geldikleri geleneksel yapıdan kopmaya başlamışlardır. Hemen hepsi bürokraside istihdam edilen ve geleneksel yapıdan kısmen kopmuş bu nesil, II. Abdülhamit dönemi muhalefetini sürdürmede, II. Meşrutiyetin ilan edilmesinde, savaşlar döneminde memleketin yönetilmesinde, milli mücadele yıllarında, cumhuriyetin kurulmasında ve inkılapların hayata geçirilmesinde aktif rol almış insanlardan oluşan bir nesildir. Özellikle bu nesil temsilcilerinin önemli bir kısmında, Tanzimat ve I. Meşrutiyet aydınının geleneksel toplumsal yapıyı dönüştürmek isteyen ancak bu yapıya bir aidiyet de duyan karakterinden daha radikal bir karaktere doğru dönüşümün izlerini sürmek mümkündür. Bu radikalleşme, dine bakışta ve din meselesine dair izlenecek siyasetler konusunda da radikal bir zihniyetin oluşmasına imkan tanımıştır. Öyle ki bu radikal zihniyetin II. Meşrutiyet döneminde din ile ilgili önemli meseleleri ezber bozucu bazı çıkışlarla tartışması ve sonrasında cumhuriyetin kurulmasının ardından toplumu da karşısına alan radikal uygulamaları gerçekleştirebilmesi, özellikle hesaba katılması gereken önemli bir hareket noktasıdır.

Dinin toplumsal ve kültürel bir gerçeklik olarak üretilmesinin önemli aracıları olarak dini cemaatler ve gruplar, Türkiye modernleşmesi sürecinde yaşanan değişimlerden ciddi bir şekilde etkilenmişler ve varlıklarını devam ettirmek için yeni stratejiler geliştirmeye çalışmışlardır. Özellikle cumhuriyet döneminden itibaren İslam'ın kültürel alandaki etkinliğinin azaltılması yönünde gelişen laiklik anlayışının ve buna bağlı olarak izlenen siyasetlerin ürettiği "öteki” söyleminin baş muhatapları "irtica"1n temsilcileri olarak görülen dini cemaatler ve gruplar olmuştur. Kamusal alanda etkilerini devam ettirme noktasında önemli bir çıkmazın içerisinde kendilerini bulan dinî cemaatler, bulabildikleri ya da üretebildikleri imkanlar üzerinden etkinliklerini sürdürmeye çalışmışlardır. II. Dünya Savaşı sonrasında demokrasiye geçilmesi ve devletin katı laiklik anlayışını değiştiren siyasetler üretme çabası, dinî cemaatler açısından yeni bir dönemin başlamasına sebep olmuştur. Yakın döneme kadar özellikle darbe dönemlerinde devletle karşı karşıya geldikleri ve laiklik üzerinden ötekileştirildikleri dönemler olmuşsa da, dinî cemaatlerin toplum hayatında oldukça etkin yapılar olarak varlıklarını sürdürdükleri de vakıadır. Bu yazıda, Türkiye modernleşmesinde oluşan kültürel bölünme açısından dini cemaatler ve gruplar tarihsel sosyolojik bir bakış açısından değerlendirilmeye çalışılacaktır. 


\section{Türkiye Modernleşmesinde Din Meselesi ve Kültürel Bölünme}

Kültürel bir yapının sosyolojik varlığı ve devamlılı̆̆ı, normlar, inançlar, değerler gibi varlığının kaynağı olan temel unsurları o kültürel yapıya bağlı olan insanların zihniyetlerinde ve pratiklerinde sürekli olarak üretebilmesine bağlıdır. Öyle ki bu üretim, sürekliliğe atıfla daima bir yeniden üretim olarak devam etmek durumundadır. Farklı kültürel yapıların ve grupların varlıklarını sürdürmeleri de bu şekildedir. Bu yüzden herhangi bir kültürel yapının kendi varlığının devamlılığını ve sürekliliğini sağlaması, yeniden üretim sürecini sağlıklı bir şekilde sürdürebilmesine bağlıdır. Toplumsallaşma ve bir toplumsallaşma biçimi olarak eğitim, gruplarda, cemaatlerde ve örgütlerde yeniden üretim mekanizmasını işleten en önemli süreçtir. Yeniden üretimin sekteye uğraması, bu tür toplumsal birimlerin sosyolojik anlamda krize girmelerine ve bu birimlere toplumsal aidiyet duyan farklı nesillerden temsilciler arasında zihniyette ve pratikte ciddi kopmaların yaşanmasına sebep olabilmektedir. Geleneksel toplum yapılarında üretim ve yeniden üretim sürecinin sürekliliğinden ve bu duruma bağlı bir şekilde değişmenin yavaş ve zor olmasından bahsedilebilir. Osmanlı modernleşmesiyle birlikte resmi bir siyaset olarak kabul edilen batıllılaşma, toplumsal alanda yeni bir kültürel üretim ve yeniden üretim sisteminin oluşturulması anlayışına karşılık gelmiştir. Böylece Tanzimat öncesinde başlayan, sonrasında hızlanan ve nesillere yayılan batılılaşma siyaseti, özellikle eğitim kurumunda yaşanan yenilenmelerle yeni bir kültürel yapının oluşmasına ve devam etmesine de imkan sağlamıştır. Batıda modernleşmenin en önemli alt süreçlerinden birisi olan okullaşma (schooling), Osmanlı modernleşmesinin de belirleyici unsurlarından birisi olmuştur. Böylece devleti kurtarma refleksine bağll, yeni nesillerin yetişmesini sağlamak amacıyla kurulan okullar, yeni kimlikler, yeni kültürel gruplar ve yeni aidiyetler üretme noktasında önemli belirleyiciler olarak dikkat çekmişlerdir. Bu kuruluşlar ve yeni nesiller açısından sosyolojik anlamda başarılı olan durum ise toplumda mevcut alt kültürel grupların dışında yeni ve farklı toplumsallık alanları ya da sosyaliteler oluşturabilmeleri ve bu alanlarda yeniden üretim mekanizmalarını işletebilmeleridir. ${ }^{1}$

Osmanlı modernleşmesi dahilinde batılllaşma hareketleriyle başlayan kültürel ayrışmanın en önemli açıklamalarından birisi, batılılaşma siyaseti sonucunda kurulan okullarda yetişen yeni nesilde pozitivist anlayışın gelişmesidir. Geleneksel yapı-

1 Konya'da geleneksel medrese eğitimi alan ve I. Dünya Savaşında Çanakkale'de ve Irak'ta asker olarak görev yapan Abdullah Fevzi Efendi'nin hatıratı, kültürel bölünmeyi özellikle din ve dindarlık üzerinden göstermesi bakımından önemlidir. Hatırat, bilhassa seküler okullardan yetişen subaylar ile halktan gelen askerler arasındaki zihniyet farklılıklarının nasıl bir duruma karşılık geldiğini örnek olaylar üzerinden nakletmiştir (bkz. Koçkuzu, 2011). 
larından kopan ya da bu yapıyla daha mesafeli bir konuma gelen yeni nesillerin en çok etkilendikleri ideoloji, bilim ve ilerleme vurgusu dolayısıyla pozitivizm olmuştur (Mardin, 2011a, s. 47-56; Karpat, 2009, s. 321). Dönemin hem Batıda hem de Batı dışı toplumlarda en güçlü ve etkili anlayışlarından birisi olan pozitivizme bağlanmak, "geri kalmışlı̆̆ı aşma" zihniyetinin ve psikolojisinin bir yansıması olarak da kabul edilebilir. Bu zihniyete ve psikolojiye sahip olanların "asr-1 terakki"nin getirdiklerinin yanında geleneksel sosyal hayatın asırlardır aynı dinamikler üzerinden devam etmesi ve mevcut yapısıyla ilerleme önünde engel teşkil etmesi arasında var olduğunu düşündükleri çelişkiye odaklandıkları tespit edilebilir. Bu bağlamda daha radikal bir değişim düşüncesine sahip aydınların ve bürokratların büyük çoğunluğu açısından dini cemaatler ve gruplar, geleneksel yapının sürdürülmesine katkıda bulunan, zamanı geçmiş, ilerlemeye engel “teolojik dönemin” örgütlenmeleri olarak kabul edilmiştir. Yirminci yüzyılın başından itibaren çok uzun yıllar Türkiye siyasetinde söz sahibi olan bu nesil temsilcilerinin bir kısmının bu cemaatlere ve gruplara zamanında var olan aidiyetleri, özellikle aile ve mahalle üzerinden çocukluk yıllarına götürülebilir. Bir kısmının hem geleneksel medrese eğitimi, hem de batılı eğitim almış olması da muhtemeldir. Atatürk'ün çocukluğunda Selanik'teki Mevlevi dergahındaki ayinlerde dinlediği musikiden etkilenmesi, Türkiye'de dindar kesim tarafından ismi Köy Enstitüleri ile özdeşleşen ve olumsuz algılanan Hasan Âli Yücel'in hem modern hem de geleneksel eğitim almış olması ve Mevlevilikten gelmesi, bu anlamda dikkat çekici örneklerdir. Bu nesil temsilcilerinin bir kısmında dinin ve geleneğin iç içe geçtiği kültürel aidiyet hafızası çocuklukta kalırken, küçük yaşlardan itibaren yatılı okullarda devam eden kapalı toplumsallaşma, yeni ve seküler bir karşı hafızayı da inşa etmiştir. Bu nesildeki iki farklı kültür hafızasının oluşumu, toplumsal yapıdaki kültürel bölünmenin bir yansıması olarak yorumlanabilir.

Osmanlı ve cumhuriyet modernleşmesinin toplumsal yapıdaki en önemli karşılıklarından birisi olan kültürel farklılaşma ve bu farklılaşmaya bağlı olarak gelişen toplumsallıklar, zaman içinde kendi varlıklarını sürdürme ve etki alanlarını genişletme amacıyla rekabet halinde olmuşlardır. Böylece kendi varlığını devam ettirme ve etki alanını genişletme mücadelesi, kültürel bölünmeyi sürdüren en önemli etkenlerden birisi olmuştur. Kültürel bölünmenin sürdürülmesi, iki farklı eğitim mekanizmasının işlemesiyle devam etmiştir. Bir tarafta önce Osmanlı döneminde yeni açılan batılı tarzda eğitim veren okullar ve ardından cumhuriyet döneminde ulus devletleşmenin zorunlu bir sonucu olarak devlet ideolojisine dayanan milli eğitim sistemi kurumlaşırken, diğer taraftan başta aile olmak üzere geleneksel kurumlar aracılığıyla devam etme eğilimindeki geleneksel eğitim sistemi de varlığını sürdürmeye çalışmıştır. Geleneksel eğitim sisteminin en önemli temsilcileri de medreseler, tekkeler ve zaviyeler olmuştur. Bu birbirine karşıt iki kültürel yapı, zihniyet 
anlamında bir çatışmanın içinde olmuşlardır. Zamanla batılılaşma taraftarı olan grup daha da güçlenip iktidar elde ettikçe geleneksel yapının dönüşmesi konusunda daha radikal adımlar atıııs ve kültürel rakiplerinin elini zayıflatmıştır (Güngör, 2007, s. 78-79). Bu mücadelenin farklı alanlarda süre giden bir iktidar mücadelesi olduğu da iddia edilebilir. Öyle ki, kültürel bölünmeye dayanan bu iktidar mücadelesinin temelinde dinin var olduğunu, bölünmenin kaynağının din anlayışlarının farklılaşması üzerinden gerçekleştiğini söylemek mümkündür.

Türkiye modernleşmesinde savaş dönemleri, olağanüstü dönemler olarak devlet tarafından halkın hassasiyetlerinin daha çok hesaba katıldığı ve popülizmin yükseldiği dönemler olarak dikkat çekmektedir. Bu dönemlerde iktidar sahiplerinin özellikle dini cemaatlerin güçlü aidiyet üreten yapılarından ve cemaat liderlerinin etkili konumlarından faydalandıkları tespit edilebilir. Yirminci yüzyılda Balkan Savaşları ile başlayan ve Milli Mücadelenin bitmesiyle son bulan uzun savaş döneminde, özellikle siyasal seçkinler tarafından toplumun din konusundaki hassasiyetinin göz önünde bulundurulduğu ve buna bağlı olarak bazı radikal fikirlerin zikredilmediği ve bu hassas konularda siyaset izlenmediği dikkat çekmektedir. Hatta bu dönemlerde dini cemaatlere ve cemaat liderlerine bazı imtiyazlar tanındığ ve özellikle bu yapıların güçlerinden faydalanılmaya çalışıldığı da olmuştur (Kara, 2006, s. 4). Cumhuriyetin ilanından kısa bir süre sonra hilafetin kaldırılması, tekke ve zaviyelerin kapatılması gibi o dönem toplumu için radikal ve ezber bozan uygulamalar, dinî cemaatler açısından önemli bir boşluğun oluşmasına sebep olmuştur. Aynı zamanda bu radikal uygulamalar, asırlardır geleneksel yapının en önemli belirleyenlerinden birisi olan dinin kamusal alandan uzaklaşmasına; dinî tarikatların ve cemaatlerin yer altına çekilerek pek çok yerde gizli-saklı örgütlenmelerine ve varlıklarını sürdürmeye çalışmalarına sebep olmuştur. Bu gelişmelerin geleneksel yapıya aidiyet duyan geniş halk kesimi ve bu yapının önemli aktörleri olan dini cemaatler açısından tam bir travma oluşturduğu tespit edilebilir.

Cumhuriyetin tek parti dönemi, pek çok dini cemaat açısından oldukça zor bir dönem olarak tecrübe edilmiştir. Aslında dini cemaatlere zihniyette ve pratikte daha mesafeli olan pek çok İslamcı açısından da benzer bir durumdan bahsetmek mümkündür. Geleneksel İslamî yapının sahihliği meselesini önemseyen ve modern dönem şartları dahilinde Kur’an merkezli yeni bir İslam anlayışının fikri ve siyasi mücadelesini veren İslamcılar da cumhuriyetin dine karşı radikal pozitivist siyaseti karşısında ötelenmişlerdir. Öyle ki, cumhuriyet sonrası dönemde geleneksel İslamî anlayışı temsil eden yapılar gibi modernleşme sürecinde ortaya çıkan bir hareket olan İslamcılık da ciddi bir fetret devri yaşamaya mecbur kalmıştır. Böylece geleneksel Müslümanlık anlayışının toplumsal hayatta en önemli taşıyıcıları ve üreti- 
cileri olan dini gruplar ve cemaatler de İslam'ın modern bir yorumunu yaparak söz konusu cemaatlerin ve grupların karşısında yer alan İslamcılar da aynı ötelenme sürecini tecrübe etmişlerdir. Oluşan yeni rejimin siyasetlerine destek olan ve doğrudan bir ötelenme psikolojisinin içinden konuşmayan Rıfailer gibi bazı grupların da benzer bir tecrübeyi yaşadıkları söylenebilir.

Harf inkılabı, ezanın Türkçe okunması, din eğitiminin önce sınırlandırılması ve daha sonra kaldırılması, Türkçe ibadet konusunda uygulamaya dönük bazı adımların atılmaya başlanması, dinin sadece ötelenmediğini; aynı zamanda bir toplum mühendisliği nesnesi olarak yeniden tanımlanarak kültürel alanda "milli din" haline getirilmeye çalışıldığını da göstermektedir. Bu toplum mühendisliği uygulamalarının Türkiye modernleşmesi sürecinde izlerini özellikle de Ziya Gökalp üzerinden takip etmek mümkündür. Reel toplumsal hayatta bütün bu gelişmelerin dini cemaatleri derinden sarstığını, ancak bir taraftan da kendi anti tezini üretecek şekilde yeni aktörlerin önderliğinde gizli saklı dini cemaat örgütlenmelerinin oluşmasını sağladığını belirtmek gerekmektedir. Bugün Türkiye'de pek çok insanın aidiyet duyduğu cemaatlerin büyük bir kısmı, bu dönemin ötekileştirme siyasetinden doğmuş birlikteliklerdir. Elbette daha eski dönemlerden silsile halinde devam eden dini cemaatler ya da gruplar bulunduğu gibi cumhuriyetin radikal laiklik siyasetinin ötekileştirmesinden kaynağını alan dini cemaatler de gelenekle bir şekilde bağ kurmuşlardır. Ancak aynı ötekileştirme siyasetinin din, mezhep ve cemaat fark etmeksizin işlediği de tespit edilebilir. Dönemin pozitivist, hatta vülger materyalist anlayışı açısından tutarlı olan durum da budur.

Türkiye modernleşmesi boyunca dini cemaatler ve grupların ait oldukları geleneklere bağlı olarak farklı anlayışları olmuştur. Özellikle geleneksel toplum yapısının üretilmesindeki rollerini cumhuriyetle birlikte kaybetmeye başlamaları önemli sosyolojik sonuçlara sebep olmuştur. Bu durum, bir tür süreksizliğin, radikal kopuşun ya da boşluğun oluşturduğu anomi durumu olarak adlandırılabilir. Din konusunda oluşan anomi durumu ya da boşluk, geleneksel ve muhafazakar değerlere sahip halk kesimi açısından dini cemaatleri dinî birikimi yeni nesillere aktarma adına önemli bir alternatif haline getirmiştir. Dinî konularda yetkin olmayan ve çocuklarının dinî eğitim alması konusunda hassasiyet gösteren aileler, dinî cemaatleri önemli alternatifler olarak görmüşlerdir. Devlet tarafından radikal bir şekilde ötelenmenin ürettiği anomi durumunun cemaatlerdeki karşılığını İmam Hatip Okulları meselesinde görmek de mümkündür. Bir devlet projesi olarak Türkiye'de İmam Hatip Okullarının yeniden açılmasına dönemin büyük cemaatlerinden tepki gösterenler olmuştur (Kara, 2014, s. 343). Bugün hâlâ bazı cemaatlerde cemaat üyelerinin çocuklarını İmam Hatip Okullarına göndermemeleri önerilmektedir. Hatta bu 
cemaatlerin yurtlarında kalan öğrenciler İmam Hatip okullarına gitmemekte, diğer ortaokul ve liselerde eğitim almaktadırlar. Bu durum, bir yönüyle güven ihtiyatını gösteren bir tavır olarak yorumlanabileceği gibi din alanında oluşan boşlukta cemaatin kendi oluşturduğu iktidar alanını paylaşmama tavrı olarak da yorumlanabilir.

Tek parti dönemi sonrasında demokrasiye ve çok partili hayata bağlı olarak siyasi popülizmin yeniden yükselmesi, dinî cemaatlerin aidiyet üretme gücünün yeniden önemli bir potansiyel olarak algılanmasını sağlamıştır. Askeri darbeler gibi siyasetin normal akışına müdahale eden uygulamalar dışında Türkiye siyasetinde dinî cemaatler, siyasete etki eden önemli aktörler olmuşlardır. Genel olarak Türkiye modernleşmesi sürecinde dinî cemaatlerin farklı dönemlerde farklı konumlarda bulunduklarını ve dönüştürülmeye çalışılan geleneksel yapıyı üretme konusunda kendilerine bir alan oluşturduklarını söylemek mümkündür. Bugün Türkiye'de daha da büyüyen, güçlenen, farklılaşan pek çok dinî cemaatin ve bu cemaatlere aidiyet duyan insanların hikayeleri, Türkiye modernleşmesinin tarihsel süreci ya da makro hikayesi dahilinde anlaşılabilir.

\section{Türkiye' de Siyasal Dönüşüm ve Dinî Cemaatler}

1950 sonrası Türkiye'nin değişmesi sadece siyasal alanda demokrasiye dönüş ve serbest seçimler sonucunda hükümet değişiminden ibaret değildir. Bu dönem, aynı zamanda kırdan kente hareketliliğin de başladığ1 ve yoğunlaştığı bir mekan değişikliğini beraberinde getirmiştir. Kıtlık ve savaş yıllarından sonra özellikle "Marshall Yardımları" dolayısıyla iyileşen ekonomi de dikkate alındığında 1950’lerin ilk yıllarından itibaren toplumda büyük bir hareketliliğin ve sosyolojik dönüşümün yaşanmaya başladığı dikkat çekmektedir. Aynı zamanda İkinci Dünya Savaşından sonra rejimin tekrar çok partili hayata dönmesi de bu yazının temel tezleri aç1sından önemli ve değinilmesi gereken bir olaydır. 1925 ile 1945 arasında sadece Serbest Cumhuriyet Fırkası'nın (SCF) kurulması ve üç ay muhalefet partisi olarak siyaset sahnesinde bulunması dışında cumhuriyet rejiminde çok partili hayata geçişle ilgili bir adım atılmamıştır. Hem milli mücadeleyi yapan esas kadroda bulunan Kazım Karabekir, Ali Fuat Cebesoy, Rauf Orbay, Refet Bele gibi isimler tarafından kurulan Terakkiperver Cumhuriyet Firkası'nın (TpCF) kapatılmasında, hem de cumhuriyetin İsmet Paşa'dan sonraki başbakanı Fethi Okyar tarafından Atatürk'ün teşvikiyle ve güvencesiyle kurulan güdümlü muhalefet partisi Serbest Cumhuriyet Fırkası'nın kapatılmasında rejimin laiklik anlayışına göre oluşan hakim irtica retoriğine başvurulmuştur. TpCF'nin kapatılması ile mürteci hareketi olarak adlandırılan Şeyh Said olayı arasında bağ kurulurken, SCF’nin kapatılmasının ardından meydana gelen Menemen Olayı da SCF ile rejim tarafından inkılapçılığa karşı bir 
Nakşibendi ayaklanması olarak tanımlanmıştır (Ahmad, 2014, s. 77-78; Tunçay, 2005 , s. 304). Menemen olayının tek parti dönemini siyasal anlamda sahiplenen kesimler tarafından bugün hâlâ karşılığı bulunan bir retoriğe karşılık gelmesi ve inkılap-irtica karşıtlığının sembol olaylarından birisi olması dikkate değerdir. Çünkü başta Derviş Mehmet olmak üzere olaya karışan tarikat mensubu insanların "esrar çektikleri” ve bu halde irticai bir ayaklanma başlattıkları, pek çok inkılap tarihi kitabında özellikle vurgulanan bir ayrıntıdır. Öldürülen asteğmen Kubilay'ın -ki öğretmen olması da burada vurgulanmalıdır- başının kesildiği ve kesilen başın bir sopanın ucuna takılarak şehirde dolaştırıldığı iddia edilmiştir. Olayın doğruluğu ya da yanlışlığının ötesinde Menemen olayı, güdümlü de olsa bir muhalefetin; hem de güdümlü muhalefetle herhangi bir ilgisi olmayan dinî grupların ötelenmesi retoriğine önemli bir siyaset alanı açılmasına imkan sağlamıştır. Asteğmen Kubilay'ın bir "devrim" ya da "inkılap" şehidi olarak tasvir edilmesi ve sembolleştirilmesi de bu sürecin bir diğer sonucudur. Dönemin gazetelerinde olayla ilgili sarıklı ve sakallı insanlar, yılan şeklinde karikatürize edilmiş ve idamların yanında diğer cezalar üzerinden "yılanın başının ezildiği” mesajı verilmiştir. Tekke ve zaviyelerin kapatılmasıyla kamusal alanda kendi dinî kimlikleriyle var olma imkanı bulamayan dinî gruplar, daha çok yer altına çekilme ve gizlenme üzerinden kendi varlıklarını yeni rejime rağmen sürdürmenin alternatif yollarını aramışlardır.

Tek parti döneminde gerçekleştirilen bazı uygulamalar, dindar insanlar ile rejim arasındaki siyasal mesafenin daha da açılmasına sebep olmuştur. Başta ezanın Türkçe okunmaya başlanması, ibadet dilinin Türkçeleştirilmesi için yapılan bazı uygulamalar ve milli eğitimde din derslerinin müfredattan kaldırılması, Türkiye'nin ulus devletleşme siyasetine bağlı olarak gerçekleştirilen din uygulamaları olarak dikkat çekmektedir. Her ne kadar Diyanet İşleri Başkanlığ1 resmî bir statüye sahip olsa da bu dönemde oldukça pasifize edilmiş bir durumda bırakılmıştır. Dinin kamusal alandan uzaklaştırılması ve bireysel bir vicdan meselesi olarak tanımlanması, yüzyıllardır kendi kimliğini din üzerinden tanımlayan insanları sosyolojik bir gerilimin içine itmiştir. Böylece köylerde ve mahallelerde devam ede gelen geleneksel sosyalitelere bağlı dinî sosyalleşmeler ciddi anlamda sekteye uğramıştır. Yüzyllardır insanların inançlarını ve pratiklerini belirleyen bir sosyal kurum olarak dinin, yeni siyasal rejim tarafından farklı bir yorumla yeniden tanımlanması ve düzenlenmesi, sosyolojik bir krize sebep olmuştur. Gücünü gelenekten alan bir sosyal kurumun kendisini yeniden üretmesi sürecinde önüne engellerin çıkması, hem din kurumunun hem de din kurumunun sosyal üreticileri olarak müminlerin farklı ya da yeni tarzlarla da olsa süregelen sosyaliteyi yeniden üretmelerine engel olamamıştır. Dine bağlı halk kitleleri, yeni tarzlarla ve savunma mekanizmalarıyla oluşan krizi aşma çabasıyla hareket etmeye ve alternatifler üretmeye çalışmışlardır. 
Elbette bu çabanın yeni sosyolojik durum bağlamında gerçekleştiğine ve değiştiğine vurgu yapmak gerekmektedir.

Cumhuriyetin kurulmasının ardından oluşabilecek siyasal muhalefetin bertaraf edilmesiyle iktidar eliyle başlanan transformasyon süreci, kültürel alana da hakim olmak amacıyla önemli adımlar atılmasıyla devam etmiştir. Osmanlı topraklarında yüzyıllardır kültürel alanın biçimlenişini ve sosyolojik olarak üretilmesini sürdüren asıl kurum din ola gelmiştir. Farklı din ve mezhep mensupları arasında kültürel alanda gerçekleşen ritüeller, toplumsal etkileşimler ve roller din temelinde tanımlanmıştır. Bu geleneksel yapının özellikle taşıyıcı temel kurumu aile olmakla birlikte, aile dişındaki kültürel üretimi sağlayan mekan, köyler ve şehirlerde de mahalle olarak öne çıkmaktadır. Mardin (2011b, s. 57), Türkiye modernleşmesinin önemli aktörlerinin eğitim kurumları üzerinden geleneksel toplumsallıktan uzaklaşmasını özellikle yatılı okul yapısı üzerinden analiz etmiştir. On dokuzuncu yüzyılda toplumda temelde iki farklı toplumsallık ya da sosyalitenin ortaya çıkması, kendi sınırlarında toplumsallıklarını üretmeleri, iki farklı kültürün ve ideolojinin karşı karşıya gelmesini sağlamıştır. Cumhuriyetin ilk yıllarından itibaren genelde otoriter; bazı dönemlerde de totaliter eğilimlere sahip olan iktidar seçkinleri, toplumsal transformasyon sürecinde öncelikle kamusal alanın dönüşmesini arzu etmişler, özel alanın dönüşümünü iki yoldan; milli eğitim ve kamusal alandaki örgütlenmeler üzerinden sürdürmek amacında olmuşlardır. İktidar seçkinleri, kendi siyasal toplumsallaşma süreçlerinde de benzer tecrübeleri yaşamışlardır. Bir mekan olarak okul ve misyoner bir kanaat önderi olarak öğretmen figürünün Türkiye modernleşmesinde önemli bir yeri vardır. Öyle ki bu bağlamda aydın ve yenilikçi öğretmen ile geleneksel yapının temsilcisi ve sürdürücüsü imam arasında bir tezat olduğu propagandası sıkça başvurulan bir alg1 yönetim biçimi olmuştur. Bu karşıtlığın köklerinin özellikle meşrutiyet yönetiminin eğitim siyasetiyle net bir şekilde ortaya çıktığına dikkat çeken Berkes (2002, s. 454), muallimin, gelenek ve alışkanlıkların son güçlü bekçisi hoca karşısında konumlandığını savunmuştur. Bu algı, cumhuriyet döneminde de resmi ideoloji tarafından propaganda malzemesi olarak ciddi bir şekilde işlenmiştir. Bu konuda özellikle sinema sektöründeki pek çok örnek dikkat çekicidir.

Tunçay (2005, s. 239-240), tek parti dönemi eğitimin niteliğiyle ilgili üç önemli tespitte bulunmuştur:

1. Batılılaşabilmek için Osmanlı/İslam geçmişiyle ilgili her şeyin silinip süpürülmesini isteyen Cumhuriyet Türkiye'si, bu amacın gerçekleştirilmesinde eğitimin etkin bir rol oynamasını beklemiştir. Eğitime yalnız böyle olumsuz değil, idealist bir anlayışla, ülkeyi dönüştürmekte -altyapı öğeleri yerine- öncülük etmek gibi yapıcı bir görev de verilmiştir. 
2. Eğitime, eğitim-dışı, hatta eğitimin gerçek hedeflerine aykırı, bir rejim propagandacılığı işlevi yüklenmiştir. Çağdaşlaşmaya öncülük etme amacını izlerken, eğitimde de "kullanılan araçlar çoğu kez keyfi ve diktatörce" olmuş, uzlaşmaya, bireşime yer verilmemiştir.

3. Geleneksel dinsel eğitimin yerine, laik bir ulusal eğitim yaratılmaya çalışılmış; fakat Türk ulusçuluğunun, eğitimde önemli bir öğesi 1rkçllı olmuştur.

Yukarıda da değinildiği gibi kültürel bölünmüşlüğün cumhuriyet dönemindeki en önemli çatışmalarından birisi olan "dindar-laik" ayrılığının izleri de okullaşma üzerinden takip edilebilmektedir. Cumhuriyet, Osmanlı modernleşmesinden devam eden seküler okullaşma mirasını kendi ideolojisi temelinde sürdürmüştür. Bu süreklilikte geleneksel eğitim mekanizmalarına ağır bir darbe vurulmuştur. Tevhid-i Tedrisat kanunuyla birlikte tekke ve zaviyelerin kapatılması, ana karakteri dinî eğitim olan ve yüzyıllardır tarikatlar ve cemaatler tarafından sürdürülen bir kurumsal işleyişin önüne set çekmiştir. Ancak bu seti aşmak ya da alternatif yollarla kendi varlıklarını sürdürmek için çabalayan gruplar daima bulunmuştur ki bu durum, en küçük bir toplumsal birimin bile sosyolojik sürekliliği açısından hayati önem arz etmektedir.

Okul dişındaki kamusal alan için şehirlerde CHP’ye bağlı olarak Halkevleri, köylerde Halkodaları ve başka dernekler kurulmak suretiyle amaçlanan dönüşüm gerçekleştirilmek istenmiştir. Halkevleri kurulduktan sonra binlerce öğretmen bu örgütlere kaydolarak etkin bir rol oynamaya zorlanmışlardır (Tunçay, 2005, s. 241). Kültürel alanda hakim güç olarak varlığını sürdüren dinî cemaatlerin ve tarikatların önemli bir kısmı yeni oluşan durum karşısında boşluğa düşmüşler ve kendi toplumsallıklarını sürdürmenin yollarını da bir şekilde aramışlardır. En azından bugün Türkiye'de gerek siyasette gerekse kültürel alanda oldukça aktif ve etkili dini grupların hikayelerine bakıldığı zaman, tek parti döneminde gizli saklı, yer altında bir şekilde sorumluluk üstlenen geleneksel dinî eğitim almış öncü isimlerin çabaları dikkat çekmektedir.

Türkiye'de geleneksel halk kesimi tarafından "Allah demenin yasak edildiği dönem" olarak adlandırılan tek parti iktidarının, en azından bu kesimin hafızasında derin bir iz bıraktığını söylemek mümkündür. Öyle ki bu toplumsal hafızanın izleri ötelenmeyi yaşayan nesillerin temsilcilerinde bugün bile takip edilebilir. CHP'nin II. Dünya Savaşı sonrasında çok partili hayata geçmesi ve denetlenen ilk şaibesiz seçimlerde seçimi kaybetmesi, ötelenen toplumsal hafızanın kendisine var olmak için alan bulduktan sonra gösterdiği bir tepki olarak yorumlanabilir. Bu sonuç, CHP yöneticileri tarafından öngörülmeyen bir durum değildir. Çok partili hayata geçişten sonra, 1947 yılının Aralık ayında toplanan CHP 7. Kurultayında delegeler, cumhuriyetin kuruluşundan itibaren uygulanan din politikaları üzerine önemli tartışma- 
lar yapmışlardır (Özcan, 2015). Nitekim, CHP’nin tek başına iktidarda kaldığı son iki yılda Kur'an Kursları, İmam Hatip Okulları ve Ankara'da İlahiyat Fakültesi kurulmuş, Recep Peker gibi tek parti döneminin radikal bir isminin yerine daha 1lımlı olan isimlerden önce Hasan Saka, ardından da İslamcı geçmişi bulunan Şemsettin Günaltay başbakan olarak atanmıştır. Kurultaydan yaklaşık beş ay önce II. Meşrutiyet devrinin İslamcı isimlerinden birisi olan Ahmed Hamdi Akseki, Cumhurbaşkanı İsmet İnönü tarafından Diyanet İşleri Başkanlığına atanmıştır (Kara, 2014, s. 81). İlkokul dördüncü ve beşinci sınıflarda seçmeli din dersleri okutulmasına izin verilmiştir. Dinî açıdan bir başka önemli gelişme de hac ibadetini gerçekleştirmek için Arabistan'a gidecek olanlara döviz izni verilmesi olmuştur. Bu dönemde etkin olan bir dinî grup olarak Ticaniler, 1950 seçimlerinde CHP'yi desteklemişlerdir (Kayalı, 2012, s. 60). Dindarlar açısından Demokrat Parti döneminde devam eden göreli rahatlamayı CHP’nin 1947 kurultayından sonraki sürecin bir devamı gibi görmek mümkündür. DP, bu sürecin bir devam ettiricisi olmuştur.

Gerek tek parti döneminin son iki yllında; gerekse DP döneminde devam eden süreci anlayabilmek için demokrasi tecrübesine özellikle dikkat etmek gerekmektedir. Türkiye'de denetimli, gizli oy-açık sayım usulüne göre seçimlerin yapılması, yöneticilerin en azından seçim dönemlerinde halka hesap vermeleri gereken bir siyasal yapının oluşmasını sağlamıştır. Böylece, daha önce izlediği siyasetten dolayı hesap verme durumunda olmayan bürokrasiyi temsil eden kesim içinde atanmışlar ve seçilmişler arasında bir fark oluşmuştur. Seçilmişlerin ister istemez toplumun siyasal desteğine ihtiyaç duymaları, toplumsal kesimleri temsil eden kanaat önderleriyle bir şekilde iletişim kurmalarına sebep olmuştur. Bu siyasal ilişki biçimi karşılıklı faydanın ve çıkarın gözetildiği bir siyasal iletişim mekanizması ve dolayısıyla siyasal kültür üretilmesine katkıda bulunmuştur. 1950'li yıllara gelindiğinde toplumun önemli bir kesiminin geleneğin etkisi altında yaşadığı ve geleneksel dini grupların etkilerinin devam ettiği düşünüldügünde, dini grupları temsil yetkisine sahip olan kanaat önderlerinin bu siyasal kültür yapısında öne çıkmaları beklenebilir bir durumdur. Üstelik sadece DP'liler ve diğer muhalif partiler dini grup önderleriyle iletişim kurma çabası içinde olmamışlardır. Aynı zamanda CHP'li yöneticiler de, çok partili hayata geçişle birlikte özellikle kırsal kesimlerde bulunan kanaat önderlerine ulaşmayı önemsemişlerdir. Kahraman'ın (2010, s. 363-365) tespit ettiği üzere CHP, 1950 seçiminden itibaren DP döneminde yapılan seçimlerde kırsal kesimden ve köylülerden önemli ölçüde destek almıştır. Bu gerçeğin göz ardı edilmesinde klasik CHP'li tipinin doğrudan bürokrasiyle ilişkili, eğitim almış, resmi ideolojiyi benimsemiş ve daha çok memurluk yapan birisi olarak algılanmasının payı olduğu düşünülebilir. Halbuki demokrasiye geçişle birlikte dindarların lehine bir siyasal popülizmin üretilmesine ilk ve en önemli katkıları 1947 Kurultayı sonrasında CHP vermiştir. 
Türkiye'de demokrasiye ve çok partili hayata geri dönüşün belli bir kesim tarafından bir "karşı devrim" olarak tanımlanması da din ve laiklik tartışmaları üzerinden gerçekleşmiştir. Bu kesimin sözcüleri, "demokrasiye erken geçildiği” tezini ileri sürerken, cumhuriyetin ruhunu benimsemiş nesillerin henüz yetişmediklerini ya da sınırlı sayıda olduklarını, batılılaşmanın hedeflerine ulaşmadığı gibi akamete de uğradığını dolaylı olarak iddia edegelmişlerdir. Bu gelişmelerin sağlanamaması yüzünden henüz karanlıktan kurtulamamış halkın aynı zamanda önemli bir siyasal propaganda ve popülizm aracısı olarak dinî söylemlere itibar ettiğine işaret edilmektedir. Elbette bu retoriğin temelinde laikliğin bu kesim için işlevsel bir şekilde iktidar alanı ve sosyolojik bir ayrıcalık üretmesi gerçeğinin bulunduğu da göz ardı edilemez (Mahcupyan, 1998, s. 67-68). CHP’nin TpCF gibi kendi karşısında oluşan muhalefetin yanında, SCF olayında olduğu gibi kendi oluşturduğu muhalefete karşı da daima en önemli ve etkili siyasal retoriği laiklik olmuştur. Laiklik retoriği ve siyaseti, geleneksel dindar gruplar ile CHP'nin mesafeli bir ilişki kurmasına sebep olduğu gibi Türkiye siyasi tarihi boyunca CHP karşısındaki siyasi partilere önemli bir destek potansiyeli de üretmiştir. Kendi katı laiklik anlayışı Türkiye'nin demokrasi tarihi boyunca CHP'nin önemli bir sorunu olmuştur. Bu yüzden belli gruplarla yakınlaşmalar, seçimlerde ilahiyatçı adaylar göstermek ve bu adayları özellikle vitrine sunmak genelde başvurulan yollar olmuştur. Ne var ki bu retoriğin aşılması konusunda CHP'nin hem kendi tabanıyla hem de siyasetçileriyle hâlâ ortak bir siyaset üretemediğini söylemek mümkündür.

\section{Sonrası Toplumsal Dönüşüm Açısından Dini Cemaatler}

Dinî gruplar ve cemaatler, tek partili dönemle kıyaslandığında çok partili hayat boyunca genelde kendi toplumsallıklarını sürdürebilme adına daha fazla imkan bulmuşlardır. Elbette askeri darbelerde ve özellikle de 28 Şubat döneminde tek parti döneminin laiklik retoriğinin ve rejim reflekslerinin öne çıktığına dikkat çekmek gerekmektedir. 1950 seçimlerinden itibaren her seçim döneminde din, bir şekilde seçimin ana gündem maddelerinden birisi ola gelmiştir. Yukarıda değinilen kültürel bölünmenin din üzerinden yaşanması, aynı zamanda kültürel bir rekabet alanı olan siyasetin de ana meselelerinden birisinin ve belki de birincisinin din olmasina sebep olmuştur. Bir kısmı, siyaset alanında kendilerine imkan bulan, siyasetle mesafeli olsalar da kamusal alanda daha fazla yer edinebilen gruplar da bu firsattan faydalanmayı bilmişlerdir.

Türkiye modernleşmesinin temelde siyasi bir süreç olarak işlemesine bağlı pek çok mesele gibi dini gruplar ve cemaatler konusunun en önemli boyutlarından birisi siyasi bir mesele olarak gelişmesidir. Dini gruplarda ve cemaatlerde laiklik si- 
yasetine bağlı olarak yaşanan ötelenmenin motive edici bir rolü olduğunu da göz önünde bulundurmak gerekmektedir. Cumhuriyet tarihi boyunca etkin olan ve zamanla nicelik açısından küçümsenmeyecek bir potansiyele ulaşan Nurculuk, Süleymancılık, Işıkçılık, İskender Paşa gibi cemaatler, temel motivasyonlarını laiklik siyasetinin uygulamalarından elde etmişlerdir. Gerek bu cemaatlerin kendi mensupları; gerekse doğrudan aidiyet duymayan sempatizanları açısından söz konusu ötelenme siyasetinin dini alanda oluşturduğu boşluk kendilerini siyasi olarak tanımlamada önemli bir meşruiyet kaynağı olmuştur. Demokrasiye dönüş, Türkiye modernleşmesi açısından önemli bir dönüm noktasıdır. Çünkü demokrasi, halkın aidiyet kaynaklarının önemsenmesini, siyaset açısından hesaba katılmasını sağlamıştır. Darbe dönemlerinde bürokratik otorite kendi hassasiyetleri üzerinden kendi varlığını hatırlatmış olsa bile, darbelerden sonra yeniden rekabete dayalı demokratik bir siyasal sisteme dönülmesi, siyasetçiler açısından dini grupları ve cemaatleri yeniden hesaba katmayı gerektirmiştir. Burada karşılıklı, pragmatist bir ilişkinin sürekli olarak kurulduğu dikkat çekmektedir.

Türkiye'nin 1950 yılına kadarki modernleşme süreci dönemsel farklılıklara rağmen devlet merkezli bir süreç olarak değerlendirilebilir. 1950 sadece demokratik yolla bir iktidar değişimi olmanın ötesinde, daha önce de değinildiği üzere Türkiye'de kırsaldan kentlere doğru mekan hareketliliğinin de başladığı ve giderek yoğunlaştığı bir milada karşıllk gelmektedir. Öyle ki Türkiye'de dönüşen sadece siyasal yapı olmamıştır. Aynı zamanda ekonomi, eğitim ve yerleşik yapı da değişmeye başlamıştır. Yaşanan sürecin geleneksel yapıyı da dönüştürmesi, var olan toplumsal kurumların ve örgütlenmelerin yeni şartlara uyumunu önemli bir mesele olarak öne çıkarmıştır. Dinî cemaatlerin önemli bir kısmının bu dönüşüm sürecinde aktif rol aldıkları söylenebilir. Kentlere uyum sağlama arayışındaki kitlelerin mobilizasyonunu ve entegrasyonunu sağlama noktasında dini cemaatler, taşıyıcı bir rol oynamışlardır. Söz konusu entegrasyonun iki yönlü işlediği söylenebilir. Bir taraftan kentlere yeni göç eden ve daha çok gecekondu bölgelerinde yaşayan insanlar açısından geleneksel İslami anlayışın devamlılığını sağlamaları açısından dini cemaatlerin merkezi bir konumu vardır. Diğer taraftan kendi varlıklarının sürekliliği ve yeniden üretimi açısından dini cemaatler, köylerden kentlere göç eden insanlara ihtiyaç duymuştur. Böylece, her iki kesim de sürekliliklerini diyalektik bir ilişki halinde birlikte sürdürmüşlerdir.

Türkiye modernleşmesinin dönüşümü açısından mekan hareketliliğinin özellikle dikkat çekici bir yönü vardır. Söz konusu hareketlilik, devlet merkezli ve kontrollü bir süreç olarak devam etmediği için bir tür "kendinde modernleşme" olarak ortaya çıkmış ve devam etmiştir. Böylece on sekizinci yüzyılın sonundan itibaren 
takip edilebilen devlet merkezli modernleşme karşısında farklı, alternatif bir yenilenme süreci başlamıştır. Devlet bu süreci kontrol etmediği ya da edemediği gibi 1950'li yıllardan itibaren bu alternatif modernleşme daha önce oluşan kültürel bölünmenin siyasette, ekonomide, eğitimde ve daha başka alanlarda yeni görünümler arz etmesine sebep olmuştur. Dini cemaatler ise başından itibaren bu alternatif modernleşmenin merkezi bir yerinde bulunmuşlardır. Bu gelişmelere bağlı olarak dini cemaatlerin insan potansiyeli artmış ve dini cemaatler önemli sosyal sermaye imkanlarına sahip olmaya başlamışlardır. Kırsal kökenli insanların eğitim imkanlarını sağlama adına yatılı eğitim hizmetleri vermeleri, iş bulma ve hazır bir iletişim ağına insanları dahil etmede imkanları, dini cemaatlere yetişen bu insanların potansiyellerinden faydalanma imkanı sağlamıştır. Bu yüzden bu gruplar açısından eğitim mekanizması son derece önemli, hatta hayati bir işlev görmüştür. Eğitim, dini grupların ve cemaatlerin hem kendi devamlılıklarını sağlamış, hem de kitlelerin hareketliliğine müdahil olma konusunda dini cemaatleri ayrıcalıklı bir konuma yerleştirmiştir.

Türkiye'nin yeni demokratik rejimi, dini cemaatlerin 1950'li y1llardan itibaren güçlenmeleri ve ciddi bir insan potansiyeline sahip olmaları gerçeğinden bağımsız değerlendirilemez. 1960'lı yıllarda güçlenen Adalet Partisi ile dini cemaatler arasındaki ilişki bu konuda daha sonra da devam eden popülizme dayanan faydacı bir ilişki biçimini ortaya koyması açısından manidardır. Süleyman Demirel, 1964 yılında Adalet Partisi genel başkanlığına seçilmesinden sonra dini cemaatlerle ve özellikle de Nurcu gruplarla yakın temas halinde olmuştur. Süleyman Hilmi Tunahan'dan sonra Süleymancılar'ın başına geçen Kemal Kacar, 1965 seçimlerinde Osman Bölükbaşı'nın Millet Partisi'nden, 1969 ve 1977 seçimlerinde ise Süleyman Demirel'in Adalet Partisi'nden milletvekili seçilmiştir. Türkiye siyaset hayatının en önemli isimlerinden birisi olan Prof. Dr. Necmettin Erbakan, İskender Paşa cemaatinin bir üyesi olarak ve cemaat lideri Mehmet Zahit Kotku'nun icazetiyle siyaset sahnesine çıkmış ve Milli Nizam Partisi'ni kurmuştur. ${ }^{2}$ Erbakan, kendisinin görevlendirildiğini ve ittifakla genel başkan olarak belirlendiğini iddia etmiştir (Çakır, 2004, s. 545). Nicelik olarak büyük ya da küçük pek çok dini cemaat, Türkiye'de sağ siyasetin önemli partileri ile yakın ilişki halinde olmuşlardır. Sağ siyasetin dini cemaatler ile yakın temasının en önemli sebebi, siyaset sahnesinde CHP karşısında konum-

2 İskender Paşa cemaatine bağlı iki isim Necmettin Erbakan ve Turgut Özal, Türkiye siyasetinde önemli yerlere gelmişlerdir. Bu iki ismin bir başka dikkat çekici özellikleri ise, alanlarında başarılı mühendisler olmalarıdır. Bir taraftan Türkiye'nin modernleşme sürecinin ayırt edici okullarından mezun olmaları, bir taraftan da geleneksel dini yapıların devam ettiricisi bir cemaate yakın olmaları, Türkiye'nin yakın tarihinin sosyolojik okuması açısından da ilginç bir durumdur. 
lanmasıdır. CHP'nin radikal modernleşme siyasetinden ötelenmeleri dolayısıyla dini cemaatlerin büyük çoğunluğu ile sağ partiler arasında ortak bir siyaset dilinin üretilmesi daha kolay olmuştur. Ayrıca dini cemaatleri sağ siyasi partileri desteklemeye yönlendiren önemli sebeplerden birisi de antikomünizmdir. Antikomünizm, çok partili hayat boyunca Türkiye'de sağ siyasetin en önemli temellerinden birisi olmuştur. Dini cemaatler açısından komünizm, toplum için en ciddi tehlikelerin başında kabul edilmiştir. CHP karşıtlığının yanında antikomünizm anlayışının da dini cemaatleri önemli ölçüde sağ siyaseti desteklemeye yönelttiği zikredilmelidir. Ayrıca 1960'lı yıllarda CHP'nin kendi siyasi konumunu “Orta'nın Solu” olarak tanımlaması, hem sağ siyasetçilerin hem de dini cemaatlerin CHP’ye karşı konumlarını meşrulaştırmaları açısından önemli bir gelişme olarak kabul edilebilir.

Siyasetçiler açısından dini cemaatler ile kurdukları ilişkilerin sağladığı en önemli fayda şüphesiz, dini cemaatlerin sosyal sermayelerinden faydalanarak siyasi destek sağlamak olmuştur. Siyasetçilerle ilişkiler, dini cemaatler açısından hem siyasette alan açmaya hem de kendi varlıklarını büyüyerek sürdürmeye imkan tanımıştır. Bu büyüme elbette siyaset alanıyla sınırlı kalmamış, siyasetin temelde kaynakların elde edilmesine ve dağıtılmasına dayanması dolayısıyla dinî cemaatlerin ekonomi, eğitim gibi alanlarda da büyümelerine sebep olmuştur. Dini cemaatlerin siyasetle ilişkileri, bir çeşit patronaj ilişkisi olarak gelişmiş ve devam etmiştir. Güç ilişkisini karşılıklı fayda edilmesi üzerinden inşa eden patronaj, her iki tarafın da işine gelen bir siyasi iletişim biçimini üretmiştir ve üretmeye de devam etmektedir.

Dini cemaatleri Türkiye'nin demokrasi tecrübesinin önemli siyasal aktörleri olarak görmek mümkündür. Elbette bütün dini cemaatler açısından siyasette aynı aktif pozisyondan ya da görünürlükten bahsedilemez. Ancak siyasi partilerle ve devletle mesafeleri farklı farklı kurulsa bile dini cemaatler, Türkiye siyasetinde önemli bir yerde durmaktadır. Türkiye siyasi ve demokrasi tarihinde darbeler; gerek siyasi tarih açısından, gerekse Türkiye modernleşmesi açısından önemli dönüm noktalarıdır. İstisnasız hemen her askeri darbede laiklik, darbenin gerekçeleri arasında zikredilmiştir ve özellikle vurgulanmıştır. Darbecilerin "rayından çıkan" modernleşmeyi yeniden rotasına koyma iddiaları dolayısıyla, alternatif modernleşmelere de karşı bir duruşları olagelmiştir. Dini cemaatler, doğrudan ya da dolaylı şekillerde bu darbelerin muhatapları olmuşlardır. 28 Şubat, bu konuda doğrudan dini grupları ve cemaatleri hedef alması noktasında özellikle üzerinde durulması gereken bir darbedir. 1997 yılının Ramazan ayında Başbakan Necmettin Erbakan'ın başbakanlık konutunda dini tarikat ve cemaat liderlerine iftar vermesi, olayın medya tarafından "olağanüstü” bir gelişme olarak kamuoyuna sunulması, Ali Kalkancı ve Müslüm Gündüz gibi cemaat lideri olarak tanıtılan insanlar üzerin- 
den sürekli olarak medyada dini cemaatler aleyhine yayınların yapılması, 28 Şubat 1997 tarihinde irticanın terörden bile daha tehlikeli olduğu vurgusuyla daha önce gerçekleşenlerden farklı tarzda bir Milli Güvenlik Kurulu toplantısı yapılmasına sebep olmuştur. 28 Şubat darbesi, 1960’tan itibaren gerçekleşen darbelerden farklı bir işleyişe sahip olması dolayısıyla "postmodern darbe" olarak tanımlanmış ve kabul edilmiştir. Sonuçta Necmettin Erbakan ve partisi hükümetten düşürülmüş, laiklik ile ilgili hassasiyetleri yerine getirecek alternatif bir hükümet kurulmuş ve Refah Partisi'ne kapatılma davası açılmıştır. Nitekim bütün siyasi tarihimiz boyunca dini cemaatleri tek bir çizgi etrafında değerlendirebilmek mümkün değildir. Dini bir cemaat olarak faaliyetlerine başlayan ve daha sonra pek çok farklı alanda takiyeci bir anlayışla örgütlenen Fethullahçılar gibi 28 Şubat sürecine destek veren ve siyasi alanda darbecilerle aynı üslubu kullanan gruplar da olmuştur. Üstelik Fethullahçıların, 15 Temmuz 2016 tarihinde gerçekleşen darbe girişiminin doğrudan aktörleri oldukları iddia edilmiş ve genelde Türkiye tarihi, özelde din sosyolojisi alanı açısından üzerine derin analizlerin yapılması gereken ciddi bir olayın yaşanmasına sebep olmuşlardır.

28 Şubat süreci ve sonrasında yaşananlar dini cemaatlerin belli dönemlerde yer altına çekilmeleri ve belli dönemlerde kendilerine alan açmak için yeniden görünür olmaları üzerinden devam etmiştir. 2002 seçimlerinden sonra Adalet ve Kalkınma Partisi'nin iktidar elde etmesiyle devletin kendi içinde devam eden siyasi mücadelelerde diğerlerine göre daha aktif bir şekilde Fethullahçı örgütlenme dikkat çekmiştir. Eğitim, medya, sivil toplum ve bürokrasi alanlarında ciddi bir büyüme gerçekleştiren bu cemaat, Ak Parti döneminde bürokrasideki hakimiyetini arttırmış, elde ettiği güce dayanarak 2013 yılının sonunda Ak Parti hükümetiyle de doğrudan bir çatışmanın içine girmiştir. Üstelik bu çatışma, Fehullahçı örgütün bürokraside, medyada, sivil toplumda ve akademide elde ettiği araçları etkin bir şekilde kullanması ve siyasi desteğini Ak Parti'den çekmesi üzerinden devam etmiştir. 2014 y1lında gerçekleşen yerel seçimlerden ve cumhurbaşkanlığı seçimlerinden başarıyla çıkan Recep Tayyip Erdoğan, bu grubu bir “terör örgütü” olarak tanımlamış ve iç ve dış siyasette bu örgütle mücadeleye öncelik vermiştir. 15 Temmuz 2016 tarihinde gerçekleşen askeri darbe girişimi, askeri bürokraside örgütlendiği bilinen ancak bu örgütlenmenin hangi boyutlarda olduğu tahmin edilemeyen Fethullahçı örgütün, bir taraftan "dindarların okuması, yetişmesi" bir taraftan da "hoşgörü, uzlaşı" gibi söylemlerle toplumun farklı kesimlerinde kendisini meşrulaştıran bir dini cemaat söyleminden zamanla geldiği aşama dikkat çekicidir. Uzun süredir devam eden Ak Parti hükümeti boyunca dini cemaatler meselesi daha da dikkat çeken, görünür hale gelen yeni boyutlar kazanmıştır. Özellikle sosyal medya kullanımının artması, dini grupların ve cemaatlerin de yeni dijital imkânlardan faydalanmaya başla- 
maları, hükümetin Fethullahçılar ile verdiği kavganın oluşturduğu yeni ortam ve pek çok dini cemaat açısından ortaya çıkan yeni fırsatlar, Türkiye modernleşmesi açısından dini cemaatler konusunu farklı boyutlara taşımaktadır. Özellikle de 15 Temmuz darbe girişiminden sonra bu mesele bambaşka bir boyut kazanmıştır.

\section{Sonuç}

Türkiye'de dini gruplar ve cemaatler, geleneksel İslam anlayışının yaşanmasında ve nesillere aktarılmasında merkezi bir yerde bulunan sosyal yapilardir. Modernleşme tarihinin bir yönüyle bir sekülerleşme tarihi olması, dini cemaatleri bu süreç açısından önemli kılmıştır. Bir taraftan yenilenmeye çalışılan bürokratik kurumlar ve Batılı tarzda yetiştirilmeye çalışılan yeni nesiller ile diğer taraftan köklerini gelenekten alan ve sosyal bir gerçeklik olarak dinin yeniden üretilmesini sağlayan dini cemaatler, Türkiye modernleşmesinin zamanla yaşanan sosyolojik krizinin iki tarafını temsil etmişlerdir. Osmanlı son dönemi ve cumhuriyet modernleşmesinin elitlerinin geleneksel toplumsal üretim mekanizmalarından farklı bir sosyalleşme sürecini tecrübe etmeleri ve pozitivizmi gelenekselliğe ve geri kalmışlığa alternatif bir zihniyet olarak içselleştirmeleri, özellikle dikkat edilmesi gereken bir ayrıntıdır. Pozitivizmin bilimi ve ilerlemeyi önceleyen anlayışı açısından dini hayatının merkezinde kabul eden geleneksel toplumsal yapı, insanlık tarihinin geri kalmışlığına ait ilerlemeyi engelleyici bir unsur olarak kabul edilmiştir. II. Meşrutiyet sonrasında ve özellikle cumhuriyetle birlikte söz konusu pozitivist anlayış, radikal bir tarzda hayata geçme imkanı bulmuş ve kendi varoluşunu laiklik üzerinden inşa etmeye çalışmıştır. Söz konusu laiklik anlayışının karşısında en önemli muhalefet potansiyelini ise dini gruplar ve cemaatler oluşturmuştur. Cumhuriyetin radikal modernleşme adımları dolayısıyla dini gruplar ve cemaatler, kendi varlıklarının devamını sağlamak amacıyla büyük ölçüde kamusal alandan çekilmişler ve gizli örgütlenmeler yoluyla varlıklarını sürdürmeye çalışmışlardır.

Türkiye'de demokrasiye dönüşle tek parti yönetiminin son bulması, halkı hesaba katmayan jakobenist toplum mühendisliği anlayışından belli ölçüde vazgeçilmesine sebep olmuştur. Siyasi iktidarı elde edebilmek için halk desteğine duyulan ihtiyaç, ister istemez laiklik konusundaki katı tavrın değişmesini ve siyasetçiler açısından toplumun geleneksel dindar kesimlerinin daha çok hesaba katılmasını beraberinde getirmiştir. Böylece demokrasi tarihi boyunca izlenebilecek olan siyasetçilerle dini cemaatler arasında karşılıklı fayda elde etmeye dayanan bir ilişki biçimi oluşmaya başlamıştır. Bir taraftan siyasetçiler, dini cemaatlerin siyasi desteklerini almaya çalışmışlar, diğer taraftan dini cemaatler de kendilerine alan açmaya çalışmışlardır. 1950’li yıllar aynı zamanda Türkiye'nin kırdan kente göçle başlayan 
önemli dönüşümleri yaşadığı bir döneme karşılık geldiği için dini cemaatler, söz konusu mekan hareketliliğinde entegrasyonu sağlayan önemli aracılar olarak işlev görmüşlerdir. Bu dönüşüm süreci, dini cemaatleri o zamana kadar devlet merkezli devam eden modernleşme sürecine alternatif yeni bir değişim sürecinin önemli taşıyıcıları haline getirmiştir. Dini cemaatlerin zaman zaman görünür hale gelen etkinliklerindeki artışın ve güçlü insan potansiyellerinin temelinde yer alan sosyolojik gerçeklerden birisi de bu durumdur.

Türkiye modernleşmesi, temelde siyasal bir süreç olarak işlediği için, dini cemaatler de siyasetle açık ya da gizli ilişkili olmuşlardır. 1960’lardan itibaren doğrudan cemaatleri temsil eden isimler, daha yoğun bir şekilde siyaset sahnesinde yer almaya başlamışlardır. Türkiye sağ siyasetinde dini cemaatlerin önemli bir ağırlığı olmuştur. Bununla birlikte darbe dönemlerinde doğrudan ya da dolaylı olarak dini cemaatler darbenin muhatapları olmuşlardır. Özellikle 28 Şubat, tek parti döneminin karikatürize edici irtica retoriğini bu gruplara yöneltmiş ve Türkiye modernleşmesinin sosyolojik krizini yeniden gün yüzüne çıkarmıştır. Elbette bir dini cemaat yapılanması olarak ortaya çıkan ve sonunda terörü araç olarak kullanıp askeri bürokrasideki örgütlenmesiyle 15 Temmuz 2016 tarihinde sivil siyasi iktidara darbe girişiminde bulunan Fethullahçı örgüt, siyasi tarihimiz açısından bambaşka bir tecrübeye karşılık gelmektedir. Ne var ki Ak Parti dönemi, dini cemaatler açısından yeni bir döneme girilmesine sebep olmuştur. Bugün dini gerçekliğin dijital üretimine katkıda bulunan, söylemleriyle ve polemikleriyle daha açık bir şekilde görünen cemaatler dikkat çekmektedir. Nicelikteki artışın yanı sıra sosyal sermayelerindeki artış da dini cemaatleri önemli sosyolojik olgular olarak görmeyi gerektirmektedir. Bir şekilde başından itibaren Türkiye modernleşmesinde yer edinen bu sosyal yapıların bundan sonraki süreçte ve özellikle de 15 Temmuz sonrasında yeniden gündem oluşturacakları ve etkin olacakları öngörülebilir bir durumdur. Ancak 15 Temmuz kalkışmasından sonra dini cemaatler meselesi, daha önce kabul edildiği gibi konuşulabilecek bir mesele olmaktan çıkmıştır. 


\title{
Religious Groups in the Face of Turkey Modernization
}

\author{
Mahmut Hakkı Akın
}

Religion and laicism in the context of Turkey's modernization is among the most popular and debated topics in the field. A significant number of contributors to the field have argued that the process can also be regarded as secularization at the same time. At different turning points of Turkey's modernization, the issue of religion emerged in the agenda. Because of religion is the most fundamental institution that determines the traditional social structure and social differentiation, the changes that have taken place due to the modernization of Turkey have been interpreted around the issue of religion. The first century of modernization focused on the reshaping bureaucracy, it can not be said that modernization had a direct confrontation with the people on the basis of religion. However, during the Ottoman modernization, religious groups and communities, which were the most important bearers and producers of traditional religious structure, paid attention to relations with the state. Therefore, the removal of the janissaries was not merely a change in the military scene; it also meant redefining the position of a religious community relative to the state. Control and accreditation of the religious field was an understanding that had been maintained in the Ottoman state tradition and had also continued in the Republic. If we consider the modernization process of Turkey also as a state project, it will be better understood why religion has a central position throughout the whole process.

One of the most important consequences of the transformation in the bureaucracy during the modernization process of the Ottoman period was the cultural division which continued in the Republic's modernization process. This cultural division was interpreted as religion-centered division, because the culture which 
determined the everyday life stems from religion. The new generation, educated in modern schools and later employed in the bureaucracy, has begun to have more distance with the traditional culture that continues in the villages and as well as in the cities and the quartiers. Given that Turkey's modernization is also a schooling process, there has been a significant distance between the traditional institutions and the modern institutions. This cultural division has manifested itself in space preferences, consuming practices, political preferences etc. Since traditional culture produces legitimacy through religious codes, attitudes and practices beyond tradition can be regarded as outside religious and social reality too.

One of the most important issues in the modernization of Turkey as a westernization process is the question of how to live a modernized environment with a traditional Islamic understanding and with positivist interpretation that still lives in the theological period and is itself sociologically productive. Positivism is one of the most influential western ideologies in the modernization of Turkey. In this sense, it is possible to follow the traces of positivist history and society during the modernization of Turkey. So that there is an acknowledgment of positivism even in the question of "Is Islam an obstacle to progress", one of the most important and still debated questions of process. Over time, different answers have been given to this question. Along with the II. Constitutional period, the arguments that Islam is also a religion and that the progress in the West is a movement against religion was strongly defended. At the same time, this thesis also found more supporters.

The first quarter of the twentieth century was a time of great controversy in terms of modernization of Turkey and at the same time it included a period of wars for many years. From the beginning, Islam was beneficial in order to create a powerful public opinion to provide public support during wars. Especially the War of Independence in Anatolia was undertaken with an Islamic rhetoric. Here it is especially important that Islam is the most common phenomena for people. Another Islamist propaganda of the War of Independence was towards the Sunni Islamic world. This war was also announced to the Muslims of the world as a war for the caliphate.

After the War of Independence ended in victory, the divisions among those who had different political views in the process of establishing the republic began to become clearer. The fact that the ruling elites have a positivist understanding and that they are determined to implement it at this point has led to a significant transformation in relation to Turkey's modernization. Beyond bureaucratic renewal, a new process begun, in which people are included in modernization through social engineering. Of course, this process was not realized with the support of the people; A Jacobean method had been followed. The most important objectives of the revo- 
lutions were to accelerate Westernization and to provide integration with Western civilization. However, symbolic modernization has produced a contradiction with the symbolic world of the people. Resisting the revolutions was defined as "against progress" and "reactionary" by the regime. Some revolt movements are likewise described as "reactionary" movements, and religious groups have directly faced the state. In March 3, 1924, the abolition of the Caliphate, the closing of the Dervish Lodges, and the declaration of monotheism have left the religious communities, the religious producers of the cultural sphere, empty. Because of the lack of public space, many religious groups were scattered and some were hidden underground. In this period not only traditional religious groups but also groups with more modern Islamic interpretations were rendered ineffective. In the single-party period, laicism was at the forefront of the issues. And the regime was sensitive to the subject.

With the return of a multi-party system in Turkey, the issue of religion and laicism became one of the most important agendas again. During the transition period between 1946 and 1950, the Republican People's Party (Cumhuriyet Halk Partisi) decided to abandon their strict secularism policy. The main agenda of the CHP's congress in 1947 was laicism and the argument that it was not possible to reach the people with the understanding of current laicism was defended. Some radical names were liquidated from the party and some steps were taken in favor for religious masses. The decisions to allow the opening of the "Imam Hatip" ${ }^{1}$ as a course, the instruction of the religious lessons as elective courses, the release of the pilgrimage and the establishment of a theology faculty connected to Ankara University were taking place during this transition period. At the end of the transition period, religious groups and communities started a different relationship with politics in the new period, which started with the Democratic Party coming to power alone. Thus, in the political history of Turkey and in its culture, a new form of political communication has been developed that is mutually beneficial between religious communities and political parties.

In the multiparty system, political parties did not fully return to the one-party period in terms of religion and laicism. However, it can not be said that everything developed in this period by religious groups and communities developed as they wanted. Even if an important part of the religious communities support the Democratic Party government, there have been times when pressure on religious communities increased and the religious community leaders were punished. This has not created an environment in which religious communities and groups are able to perform their activities freely on public grounds. However, compared to the past, 
they have found a reasonably relaxed atmosphere and they had the opportunity to communicate with politics more easily. In addition, since the 1950s, the beginning of urbanization in Turkey has made religious communities important alternatives regarding mass migrating from the rural-to-urban areas. The efforts of immigrants to adapt to the city and to preserve traditional religious values, have allowed religious groups to grow in many ways.

The multiparty system in Turkey has been interrupted at certain intervals due to military coups. Religion and laicism issues very much featured in all the military coups that interfered with politics and the concept of laicism in the single-party period was emphasized. However, the return of democracy after the military coup ensured the come back of the ongoing relationship between benefit-based politics and religious groups mentioned above. Particularly, since the 1960s, prominent names of religious communities such as Nurcu and Süleymanc1 groups, have often pointed out that they have candidates from the Justice Party (Adalet Partisi). In the 1969 elections, Necmettin Erbakan's entry into politics by ratification from the Gümüşhanevi Dervish House sheikh and initiating the process of the creation of the party are important events in terms of religion and politics.

The September 12, 1980 military coup acted to achieve laicism on the one hand and to make religious education a constitutional obligation on the other. The military regime wanted to make religion like an institution controlled by the state, while it was in the process of returning to the understanding of the laicism of the one-party era. In the newly formed political environment, the Motherland Party (Anavatan Partisi) of Turgut Ozal, who was part of a religious community in 1983, that came to power alone. In the 1980s, religious communities began to become more active with the opportunity to find changes in the economy and politics. In the meantime, the use of tapes and videos further expanded their scope of influence. It seems that a pragmatic relationship with politics was established in these years. As a result, some associations have opened up space for them in the bureaucracy.

The years of the 90's were years when religious groups became more visible compared to previous periods. The rise of the Refah Party (Refah Partisi) raised the debate on secularism in politics again and more strongly that the party won many metropolitan municipalities, especially Istanbul and Ankara. On the other hand, the arrangement of discussion programs in which many religious community representatives also participated in private television channels gave those religious and laicism debates a platform. The 1995 election was the start of a new military and bureaucratic intervention process in which the RP won and became a ruling partner. On February 28, when compared to other military coups, laicism is separated not only from the point of view of method, but also due to the fact that the 
desire for laicism is a high blow and the attempt of reconstruction of the religious field. Turkey entered the 2000s with debates about the direct targeting of religious groups and their opposition to the regime.

The years of 2000 have been and are still being experienced as a very different period for Turkish modernization and religious communities. The Justice and Development Party (Adalet ve Kalkınma Partisi), which has been in power since 2002, has received support from a significant portion of religious communities. In the AK Party era, religious communities have become more visible on the public arena, and they continue to use tools such as television and the internet utilizing developments in technology. The most important development of this period is the struggle with the Fethullah Gulen community which had once been a political ally before 2012. The activity of a religious community in the bureaucracy, in the academy, in the media, and in civil society, then turned into a bitter political conflict. At the end of this process, a coup attempt took place on July 15, 2016, in which the mentioned community also participated. In this coup attempt, the former minions adopted the laicism rhetoric. The coup against the people and other religious groups was stopped. It is interesting to note that an organized bureaucracy with a religious congregational structure, a position in the military bureaucracy, and an action to remove a ruling party from the center, is also interesting in terms of the bureaucratic development process of Turkey's modernization. In this article, religious societies and religious communities will be evaluated in light of their historical and sociological interpretation in the context of Turkey's modernization.

\section{Kaynakça | References}

Ahmad, F. (2014). Modern Türkiye’nin oluşumu (12. Baskı). (Y. Alogan Çev.) İstanbul: Kaynak Yayınları.

Berkes, N. (2002). Türkiye’de çağdaşlaşma. (A. Kuyaş, Çev.) İstanbul: Yapı Kredi Yayınları.

Çakır, R. (2004). Milli Görüş Hareketi. Y. Aktay (Der.), İslamcılık içinde (s. 544-575). İstanbul: İletişim Yayınları.

Güngör, E. (2007). Dünden bugünden (11. Baskı). İstanbul: Ötüken Yayınları.

Kahraman, H. B. (2010). Türk siyasetinin yapısal analizi II. İstanbul: Agora Kitaplığı.

Kara, İ. (2006). Cumhuriyet döneminde tarikatlar. Demokrasi Platformu, 6, 1-20.

Kara, İ. (2014). Cumhuriyet Türkiye'sinde bir mesele olarak İslam I (6. Baskı). İstanbul: Dergah Yayınları.

Karpat, K. (2009). Osmanlidan günümüze kimlik ve ideoloji. (G. Ayas, Çev.) İstanbul: Timaş Yayınları.

Kayalı, K. (2012). Ordu ve siyaset: 27 Mayıs-12 Mart (5. Baskı). İstanbul: İletişim Yayınları.

Koçkuzu, A.O. (2011). Çanakkale cephesinde bir müderris: Abdullah Fevzi Efendi (2. Baskı). İstanbul: İz Yayınları.

Mahçupyan, E. (1998). Türkiye’de merkeziyetçi zihniyet, devlet ve din. İstanbul: Patika Yayınları.

Mardin, Ş. (2011a). Türkiye, İslam ve Sekülarizm. İstanbul: İletişim Yayınları.

Mardin, Ş. (2011b). Türkiye'de din ve siyaset (16. Baskı). İstanbul: İletişim Yayınları.

Özcan, Z. (2015). İnönü dönemi dini hayat. İstanbul: Değerler Eğitimi Merkezi Yayınları.

Tunçay, M. (2005). Türkiye Cumhuriyeti’nde tek parti yönetiminin kurulması (4. Baskı). İstanbul: Tarih Vakfı Yurt Yayınları. 